immersing a plate of glass in a shallow basin containing a concentrated solution of potassic nitrate. It is encircled by a platinum wire also covered by the liquid, and connected with the pole of a secondary battery of fifty elements. The other pole consisting likewise of platinum wire covered with an insulator is held in the hand and applied to those parts of the glass where it is designed to engrave. A flash of light is produced by every contact with the electrode, and a mark accompanies each luminous appearance. The depth and fineness of the lines described depend directly on the rapidity with which Ifie electrode is moved, and the fineness of its point.

THE Deutsche Gesellschaft für öffentliche Gesundheitspflege has appointed a commission to co-operate with the government meteorological stations, in endeavouring to obtain the daily publication of the weather observations with probabilities for the following twenty-four hours, according to the American system.

TIIE additions to the Zoological Society's Gardens during the past week include two Brown Coatis (Nasua nasica) from South America, presented by the Hon. C. H. Wynn; a Palm Squirrel (Sciurus palmarum) from India, presented by Miss Barclay; two Rock Sparrows (Petronia stulta), South European, presented by Mr. D'Arcy Thompson; an Ocelot (Felis pardalis), a Red and Yellow Maccaw (Ara chloroptera), a Yellow Snake (Chilobothrus inornatus) from South America, two Black-capped Bitterns (Butorides atricapilla) from Africa, a Four-lined Snake (Colutler quadrilineatus) from Egypt, deposited; a Yellow-cheeked Amazon (Chrysotis autumnalis) from Honduras, purchased; a Red Kangaroo (Macropus rufus), an Indian Muntjac (Cersu!us munt jac), born in the Gardens.

\section{EXTENT AND PRINCIPAL ZONE OF TFE AURORA BOREALIS}

IN the Wochenschrift fïr Astronomie, Herr H. Fritz has recently compared his " Catalogue of Polar Lights," which contains notes of all aurore which have been observed since I 846 , with a publication of Herr A. Moberg, who gives an account of all auroræ observed in Finland during the years 1846 to 1855 -some $\mathbf{I}, 100$ in number. The comparison yields some interesting results which are not without importance for the theory of the phenomenon.

It appears that out of 2,035 days of the months from August to April, upon which aurore were seen and which are entered in Herr Fritz's Catalogue, no less than $\mathrm{I}, 107$ days were autoral days in Finland. Of these 1,107 aurora 794 were simultaneously visible both in America and Europe, IOI only in Europe, while the remaining 212 were only seen in Finland. During the same period ( 1846 to 1855 ) 928 aurora were seen in Europe or America which were not visible in Finland. All these figures of course refer only to the months from August to April, since during the summer months no phenomena of this kind can be observed in Finland on account of the brightness of the nights. As Herr Moberg's observations were collected from 128 different stations in Finland, we must conclude that only a very small number of auroræ remained unnoticed. We thus arrive at the conclusion that a great number of auroræ cannot have a very widely extended sphere, or that the causes of these phenomena must often be of a very local character (this is confirmed by several observations at high latitudes), while with another part of the phenomena the extension of their sphere or district of simultaneous visibility must be very considerable. The number of aurorxe which were seen in Finland only-at least for which up to the present no data of observation elsewhere have been receivedis very small $(212$, or only 19 per cent. of the total number seen in Finland). As the frequency of the phenomena increases-at the time of the maximum-the number of simultaneous observations in Finland and America rises, while the numbers of auroræ seen in Finland and Europe only, or of those exclusively seen in Finland, decrease. This agrees perfectly with the well known law that with the increase of frequency of polar lights their intensity and sphere of visibility increase also. If we carefully take into account the less prominent phenomena the above proportions would be slightly modified, but most probably they would never prove that on any day when an aurora was visible only in a small district in Europe, another one was simultaneously seen in America. Thus the comparison made by Herr Fritz contradicts Renou's view that the phenomena in America and Europe change periodically.

Of 2,878 days on which aurors were observed in America during 1826 to 1855 , there are 1,065 on which aurore were also seen in Europe, so that at least every third observation was simultaneous in both parts of the world. For the years during which more exact observations were made, viz., from 1846 to I855, and again from 1868 to 1872 , we find that during the former period out of 1,691 auroras 657 were simultaneously observed both in America and Europe; and during the latter period out of $7 \times 5$ no less than 397 , or far more than half the number. If the catalogues were more perfect the number of simultaneous observations would, beyond doubt, be found to be still greater. Some observations made in Scotland give similar results to those dating from Finland, but their publication must at present be delayed, since the American data for comparison are still wanting.

The local occurrence of auroræ does not spexk favourably for the hypothesis which places the phenomenon among the cosmical ones. Some ten years ago Herr Fritz published his views with regard to the geographical distribution of aurorre, and constructed a system of lines which he termed Isochasms-i.e., curves of equal frequency of auroræ. The outlines of this system wete as follow :- The zone of greatest frequency and intensity of auror began near Barrow point ( $72^{\circ}$ north latitude) on the northern coast of America; thence it passed across the great Bear Lake towards Hudson's Bay, crossing the latter at $60^{\circ} \mathrm{N}$. lat., passing over Nain, on the coast of Labrador, keeping south of Cape Farewell; its further course was between Iceland and the Far Oer to the vicinity of the North Cape in Norway, and thence into the Arctic Sea. According to the observations then in posses sion of Herr Fritz, the line passed round Novaya Zemlya and Cape Tsheljuskin, approached the north coast of Asia, in the eastern part of Siberia, in the longitude of Nischni Kolymsk, and thence reiurned to karrow Point.

Now after ten years, in spite of the vastly accunnulated material of careful observations, there appears no necessity to change Ylerr Fritz's system of curves in any essential detail ; indeed certain parts of the same, which were at first only..based on probability and supposition, the part of the principal zone between the north of Norway and Nishni Kolymsk as an instance, we now know with perfect certainty to be correct. Nearly identical, perhaps entirely so, with the line of greatest frequency is the line which marks the limit of visibility of auroræ towards the pole or the equator; since to the north of the line in question the aurorse are only seen in the direction of the cquator.

\section{PARIS ACADEMY PRIZES FOR I 878}

I. F xtraordinary Prizes. - Grand prizes in the Mathematical Science. - I. The application of the theory of elliptic transcendants or abelians to the study of algebraic curves. 2. It is known that the great axis of the orbit which a planet describes round the sun is not affected by any secular inequality of the order of the two first powers of the disturbing masses. Examine if there exists in the value of this great axis secular inequalities of the order of the cube of the masses, and, in the case where these inequalities are not rigorously destroyed, give the means of calculating their sum, at least approximately. The prize is a medal of the value of 3,000 francs. 3. Study of the elasticity of crystallised bodies, from the double point of view of experiment and theory. Prize the same as No. 2.

Grand prizes in the Physical Sciences. - Study of the mode of distribution of marine animals on the littoral of France. A medal of 3,000 francs value.

An extraordinary prize of 6,000 francs will be awarded as a recompense for any progress calculated to increase the efficacy of the French naval forces.

II. Mechanics. - I. The Poncelet prize of a medal of 2,000 francs value, and a complete copy of Poncelet's works, are awarded to the work contributing most to the progress of the mathematical sciences, pure or applied, published in the course of the ten years preceding the judgment of the Academy. 2. A Montyon prize, a medal of 427 francs value, will be awarded to any one who, in the judgment of the Academy, is most deserving, by inventing or improving instruments useful to the progress of agriculture, the mechanical arts, or the sciences. 3. The Plumey prize, a medal of 2,500 francs value, awarded to the 
author of an improvement of stem-engines, or of any other invention contributing most to the progress of steam navigation. 4. The Bordin prize, a medal of 3,000 francs value, will be awarded for a satisfactory solution of the following problem:'io find the means of destroying, or at least seriously diminishinc, the annoyance and the dangers arising from the products of combustion issuing from the chimneys of locomotive engines, steamships, and manufactories near towns.

III. ASTRONOMY.-I. The Lalande prize, a medal of 542 francs value, will be awarded to the person who shall have made the most interesting observation, or to the memoir or the work most contributing to the progress of astronomy. 2. The Damoiseau prize, a medal of 5,000 francs value, will be awarded (in 1879 ) for a solution of the following question :Revise the theory of the satellites of Jupiter; discuss the observations, and deduce from them the constants they contain, and particularly that which furnishes a direct determination of the rate of light; finally, construct special tables for each satellite. 3. The Valz prize, the procects of a sum of 10,000 francs, will be awarded for the most interesting astronomical observation made during the year.

IV. Prixsics.-The Bordin prize, a medal of 3,000 francs value, will be awarded for a solution to the following :-Various formula have been proposed to replace Ampère's law on the action of the clements of currents; discuss these various formula and the reasons which may be alleged for giving the preference to one of them. 2. Three Lacaize prizes of 10,000 francs each will be awarded (in 1879 ) to the works or memoirs which have contributed most to the progress of physiology, physics, or chemistry.

V. Chemistry.-The Jecker prize of 10,000 francs will be awarded to the researches which the Academy judges best calculated to accelerate the progress of organic chemistry.

VI. Borany - I. The Barbier prize of 2,000 francs will be awarded to ansone who makes a valuable discovery in surgery, medicine, pharnacy, or botany, in connection with the art of healing. 2. The Alhumbert prize, a medal of 2,500 francz value; the subject of this prize is a study of the mode of nutrition of fungi. 3. The Desmazières prize of 1,600 francs will be awarcled to the best or most useful writing on the whole or part of cryptogamy published during the year. 4. The Shore prize of 200 francs will be awarded to the author of the best memoir on the cellular cryptogams of Europe, or on the habits or matomy of a European species of insect. 5. The I3ordin prize of $\hat{j}, 000$ francs has for its subject the following:-Explain by dirct observations and by experiments the influence which the medium exercises on the structure of plant organs (roots, stem, leaves); study the variations which terrestrial plants undergo when raised in water and those which aquatic plants undergo when forced to live in air. Explain by direct experiments the special forms of several species of maritime flora.

In medicine and surgery the Bréant prize of 100,000 francs for a cure for Asiatic cholera still stands.

One or more Montyon prizes are awarded to works or discoveries which show the means of rendering an art or occupation less insalubrious.

The competition closes on June I each year. Works sent in are not returned, and the conditions as to the use of mottoes, concealment of names, \&c., usual to such competitions are required.

\section{UNIVERSITY AND EDUCATIONAL INTELLIGENCE}

SCIENCE IN SCHOOLS.--Sir John Lubbock has given notice on an early day to move in the House of Commons that it would be desirable to modify the Code of Education by adding elementary natural science to the subjects mentioned in Article 19, c. $\mathbf{r}$.

BRESLAU. - The number in attendance at the University during the present winter is 1,253 , divided as follows among the faculties :--Theological, IOI; legal, 432; medical, $x 68$; philosophical, 552 . The University possesses one of the most valuable libraries in Germany, numbering over 400,000 volumes and several thousand valuable manuscripts.

BERN AND ZURICH. - The former University is attended at present by 410 students, the latter by 318 . Each University includes in its list nineteen female students, most of whom are preparing for medical examinations.
Libraries OF German aNI) AUSTRIAN UNIVERSTTES. - Most of the German States place annually considerable sums at the disposal of the University libraries. Bavaria gives her universities cacl $1,000 l$. for this purpose; saxony grants 1,200l. to Ielipzig; while in P'russia the sums vary from $600 \%$. for Greifswald to $2,000 \%$. for Göttingen. In Austria, although the existence of so many different languages in the empire makes special demands on the university libraric:s, the Government assistance has hitherto been exceedingly limited. We notice, however, that in a late session of the Reiclistag a new policy has bren alopted, and that the annual grants have been raised to $\mathbf{1}, 500 \%$. for the Vienna library, $1,000 l$. For that at Prague, and $800 \%$. for those in the other universitics.

ST. Peters] URG,-On January $\mathbf{I}$, 1878 , the University at St. Petcrsburs numbered 1,425 students, thirty-seven more than last year. One-seventh are in the department of IIstory and Philology, three-sevenths in Natural Sciences and Mathematics, three-sevenths in Law, and one-forty-seventh in $A$ siatic languages. The number of professors is ninety-three. The stutents are mostly very poor, and the pecuniary help given to them by the University amounted during the year to the sum of $12,000 \%$; besides which, a private society of former students paid the fees for eighty-one persons.

KiErF.--The University celebrated, during the past month, the fifty-ninth year of its existence. Although so young it is well equipped with all the necessary adjuncts of a university, and its medical faculty is regarded as the first in Russia. The number of students at present is 773 , an increase of 160 on the previous year. The majority are in the medical faculty. As in the other Russian universities, the students are recruited principally from the poorer classes, 203 being freed from the payment of lecturefees, and 723 in addition receiving stipends amountinc in the total to 36,000 roubles. A high school for ladies is at last to lis opened at the University.

\section{SCIENTIFIC SERILS}

Reale Isituto Lombardo ai: Scicnze e Letteri. Rendiconti, vol. $x$. Fasc, xix, - Reduction of chlorates to chlorides without intervention of the so-called nascent statc of hydrogen (second part), by M. Tommasi. - On the cooling of pulverulent metallic solids, by M. Cantoni.-. On temperature in relation to atual energy and the state of arggregation, by M. Grassi.-Measurement of the resistance and graduation of any galvanumeter, by NT. Grassi. $\Lambda$ school experiment and means of evaporating rapialy large quantities of liquid, by M. Brugnatelii.

Fasc. $x x$, - Other experiments on the evaporation of a liquid, by M. Cantoni.--Hypertropliy and hyperplasia, by M. Sangalli. -On the first and most recent appearance in Lombardy of the Beccafico of Provence.

Kosmes, Novenber, I877.-On the relation of Greek naturephilosophy to modern natural science, by Prof. F. Schultze. Part I, on the Ionic physiologists and the Pythagoreans.-On a mathematical law applicable to the theory of nutation, by $J$. Delbouf.-On the variations of size of coloured floral envelopes, and their effect on the natural selection of flowers, by Hermann Miiller.-A turning point in the early history of the human race, by $J$. H. Becker. Part $I$, on the state of things preceding the turning point (before the discovery and use of fire).

December, 1877.-F. Schultze, on the relation of Greek natural philosophy to modern natural science, part 2, discussing Heraklitus and the Eleatic schcol.-W. Preyer, on the nature of life.-Fritz Muiller, observations on Brazilian butterfies, part 3, dealing with the evolution of the Maracuja butterflies, and the phenomena presented by their larva, pupæe, and adult forms. - A. Maurer, on the origin of articulate sounds.J. H. Becker, on the separation and reunion of races.--The number also contains a review of $\mathrm{Mr}$. Darwin's work on the different forms of flowers, by Hermann Miiller.

\section{SOCIETIES AND ACADEMIES \\ LONDON}

Geological Society, February 6.-Prof. P. M. Duncan, F.R.S., president, in the chair.-James Adey Birds, Rev. George E. Comerford-Casey, M.A., Lieut.-Col. H. H. Godwin-Austen, Sir Willoughby Jones, Bart., and Henry Richard Ladell, M.A., were elected Fellows of the Society. - The following communi- 